\title{
ASPECTS OF VINEGARS PRODUCTION AND MARKETING IN MOLDOVA
}

\author{
Alina Boistean, ORCID ID: 0000-0002-5374-5853 \\ Technical University of Moldova, 168 Stefan cel Mare Bd., Chisinau, Republic of Moldova \\ ${ }^{*}$ Corresponding author: Alina Boistean, alina.boistean@toap.utm.md
}

Received: 03. 23. 2021

Accepted: 04. 26. 2021

\begin{abstract}
Vinegar is one of the oldest fermented products in the world and its production dates back to around 2000 BC. It is a liquid fermentation product that consists from $4 \%$ to 9\% acetic acid, which is commonly used and consumed globally, either directly or as a condiment in food. It is produced by two-stage fermentation systems, i.e., the alcoholic fermentation of sugary substrates and subsequently, the acetous fermentation (oxidation) of the ethanol into acetic acid. There are numerous different types of vinegars produced worldwide based on the raw material and the production method used. Among all the vinegars available, the most common types of vinegar, produced in different parts of the world, and including some top-quality famous products, are "cider vinegar," "balsamic vinegar," "wine vinegar," "rice vinegar," and "malt vinegar." Tropical fruit vinegars and vinegars made from any kind of agricultural surpluses are also available. The different raw materials and the methods used for the production of the different types of vinegars lead to a variety of products with distinctive characteristics. In this paper, definitions, local market and legislation and current trends in vinegar production are briefly highlighted and discussed.
\end{abstract}

Keywords: vinegar, acetification, condiment, acetic acid, manufacturers.

Rezumat. Oțetul este un produs de fermentație lichidă care conține de la $4 \%$ la $9 \%$ acid acetic, care este utilizat în mod obișnuit și consumat la nivel global, fie direct, fie ca ingredient în alimente. Este produs prin fermentarea în două etape, adică prin fermentarea alcoolică a substraturilor zaharoase și ulterior prin fermentarea acetică (oxidarea) etanolului în acid acetic. Există numeroase tipuri de diferite oțete produse la nivel mondial pe baza materiei prime și a metodei de producție utilizate. Dintre toate oțeturile disponibile, cele mai frecvente tipuri de oțet, produse în diferite părți ale lumii și care includ unele produse renumite de înaltă calitate, sunt „oțet de cidru”, „oțet balsamic”, „oțet de vin”, „oțet de orez”, și „oțet de malț ”. Sunt disponibile, de asemenea, oțete de fructe tropicale și oțete obținute din orice fel de excedente agricole. Diferite materii prime și metodele utilizate pentru producerea diferitelor tipuri de oțeturi duc la o varietate de produse cu caracteristici deosebite. În această lucrare, sunt evidențiate și discutate pe scurt definițiile, piața locală și legislația și tendințele actuale în producția de oțet.

Cuvinte-cheie: oțet, acetificare, condiment, acid acetic, producători. 


\section{Introduction}

The word vinegar comes from the French word "vinaigre" which means "sour wine". The origin of vinegar is directly connected to the discovery of wine. If wine is left open to air, it rapidly becomes acid and it turns into "sour wine". Recognizable both by its smell and its pungent taste, this liquid has a long tradition. After analyzing the history and value of vinegar, we can conclude that it is one of the beautiful and great gifts given to mankind by nature. Vinegar has been part of the human diet since ancient times, being used mainly as a condiment and food preservative; It has also been used as a base for simple medicines for men and animals, being a common product in most Mediterranean countries [1, 2]. In France in the 16th century, vinegar was made from grapes, both for home consumption and for export. In England, vinegar was made from malt and in America it is not known with certainty since when, although it is thought that it was used very early as a household product, apple juice being the one that has been used for this purpose in the U.S [3].

The production of vinegar in Republic of Moldova is carried out on a small scale compared to countries such as Spain and Italy, although currently the process of production and preparation of vinegar has been gaining importance and along with this the investigation of microorganisms responsible for the acetification process [4].

Vinegar is essentially a dilute solution of acetic acid made through the fermentation process and subsequent acetification, therefore sugar is the basis of vinegar production and any dilute solution of a fermentable sugar can be transformed into vinegar under favorable conditions. Although apple juice is the most widely used to make vinegar, any fruit or vegetable that contains an adequate proportion of sugar or other necessary and desirable substances will be used to make vinegar [5].

However, for acetification to be optimal, a series of specific requirements must be met, including both the supply of oxygen, the optimum temperature and the characteristics of the raw material as the content of sugars. The turbidity of the resulting vinegar is another problem that manufacturers are trying to eliminate in different ways. Various technological practices are used to achieve stable and clear vinegar. Clarifying vinegar with bentonite products is considered a rough but not expensive cleanup [7].

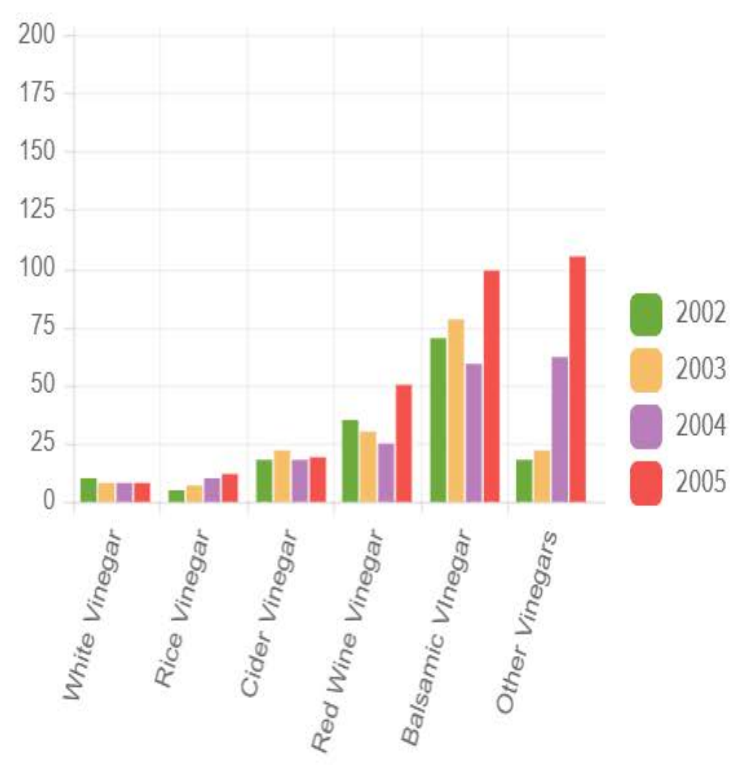

Figure 1a. Global vinegar introductions by vinegar Type (2002-2005) [10].

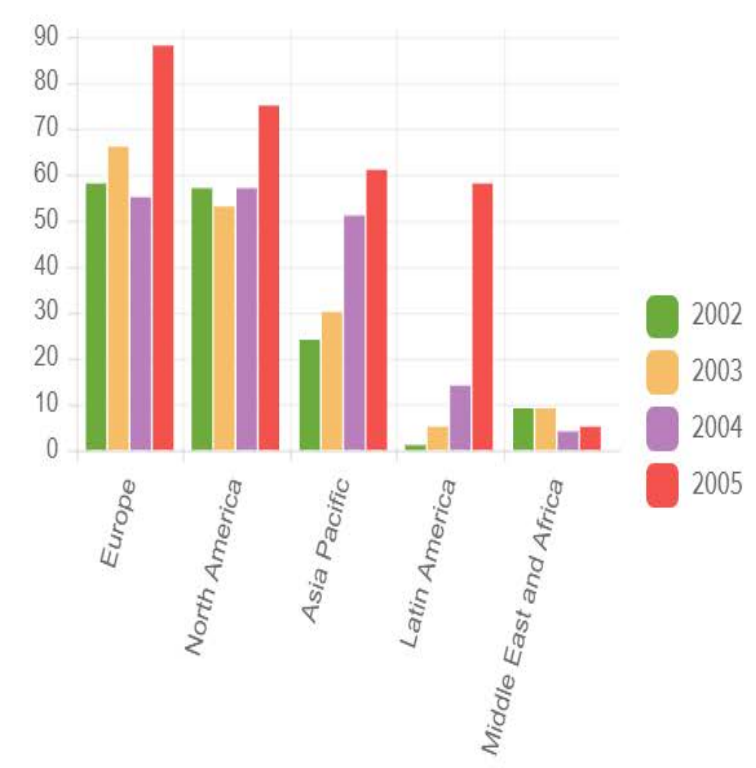

Figure 1b. Global Vinegar Introductions by Region (2002-2005) [10]. 
Economic data provided by researchers and the closeness with the wine industry (apple vinegar has a limited market share compared to wine) reveal the importance of this market and, consequently, the demand for improving understanding of economic and trade aspects of the vinegar industry. This need is imperative given that the vinegar market has received insufficient attention from researchers, who have mainly focused on specialty vinegars such as balsamic vinegar, sherry vinegar, and others [9].

Based on the data presented in Figure 1, the trend of growing interest in high-quality vinegar products was observed fifteen years ago, and this trend has not lost its interest in European countries, and now there is an increase in the production and development of the vinegar industry. IndexBox has published a new report: 'the European Union - Vinegar Market Analysis, Forecast, Size, Trends and Insights' which says that the revenue of the vinegar market in the European Union amounted to $\$ 871$ million in 2018 , picking up by $3.4 \%$ against the previous year. The countries with the highest volumes of vinegar consumption in 2018 were Germany (232 million litres), France (183 million litres) and Italy (119 million litres), together accounting for $49 \%$ of total consumption. These countries were followed by Spain, the United Kingdom, Poland, the Netherlands, Belgium, Romania, the Czech Republic, Portugal and Austria, which together accounted for a further 41\% [11].

From 2007 to 2018, the most notable rate of growth in terms of vinegar consumption, amongst the main consuming countries, was attained by Austria, while vinegar consumption for the other leaders experienced more modest paces of growth. In value terms, Italy (\$214million), Germany (\$137million) and France (\$120million) constituted the countries with the highest levels of market value in 2018, together accounting for $54 \%$ of the total market. Spain, the Netherlands, the United Kingdom, Belgium, Austria, Poland, the Czech Republic, Romania and Portugal lagged somewhat behind, together accounting for a further $37 \%$. The countries with the highest levels of vinegar per capita consumption in 2018 were the Netherlands (3,108 litres per 1000 persons), Germany (2,828 litres per 1000 persons) and France (2,800 litres per 1000 persons) [11]. This statistic on figure 2 shows the total manufacturing sales volume for vinegar in the United Kingdom (UK) from 2008 to 2019. In 2019 the sales volume of vinegar increased to an estimated 90 thousand liters [12].



Figure 2. Sales volume of vinegar manufactured in the UK in thousand liters (2008-2019) [12]. 
And also, were market forecast 2019-2025 for countries the European Union. Driven by increasing demand for vinegar in the European Union, the market is expected to continue an upward consumption trend over the next seven years. The market volume is forecast to expand with an anticipated CAGR (average annual growth rate) of $+1.1 \%$ for the period from 2018 to 2025, which is projected to bring the market volume to 1.2 billion litres by the end of 2025 [11]. The production growth trend is also observed at wood vinegar. The increase in demand for chemical-free pesticides to improves soil fertility, growing need for organic food, bio-based agricultural inputs, wide use of the product in animal feed and medical applications are the factors fuelling the wood vinegar market. There is a soar in demand for wood vinegar as it helps to improve plant growth, maintains soil fertility, enhances generation seed, reduces odor, prevents pests, rotting and weed production. Poverty alleviation is an important factor driving the market as wood vinegar can be produced at small as well as large scale in villages, using local feedstock.

As per the report published by Fior Markets, the global wood vinegar market is expected to grow from USD 1.34 Billion in 2017 to USD 2.09 Billion by 2025 at a CAGR of $5.7 \%$ during the forecast period 2018-2025 [13]. The upward trend is observed not only in the production and consumption of vinegar, but also in the field of scientific research. Zhang, X. L., et al. (2020) analyzed the trend of research results and citation in the field of vinegar science. The trace of published articles shows the development speed and progress of research, while also reflecting the concentration of research in a certain field. As shown in figure 4, although some fluctuations were observed, the number of papers published increased over time. The number of published papers rose from 19 in 1998 to 97 in 2018. It should be noted that the retrieved number of published papers in 2019 was only 44; this is because records for only half of a year were available by the end of the retrieval date [14].

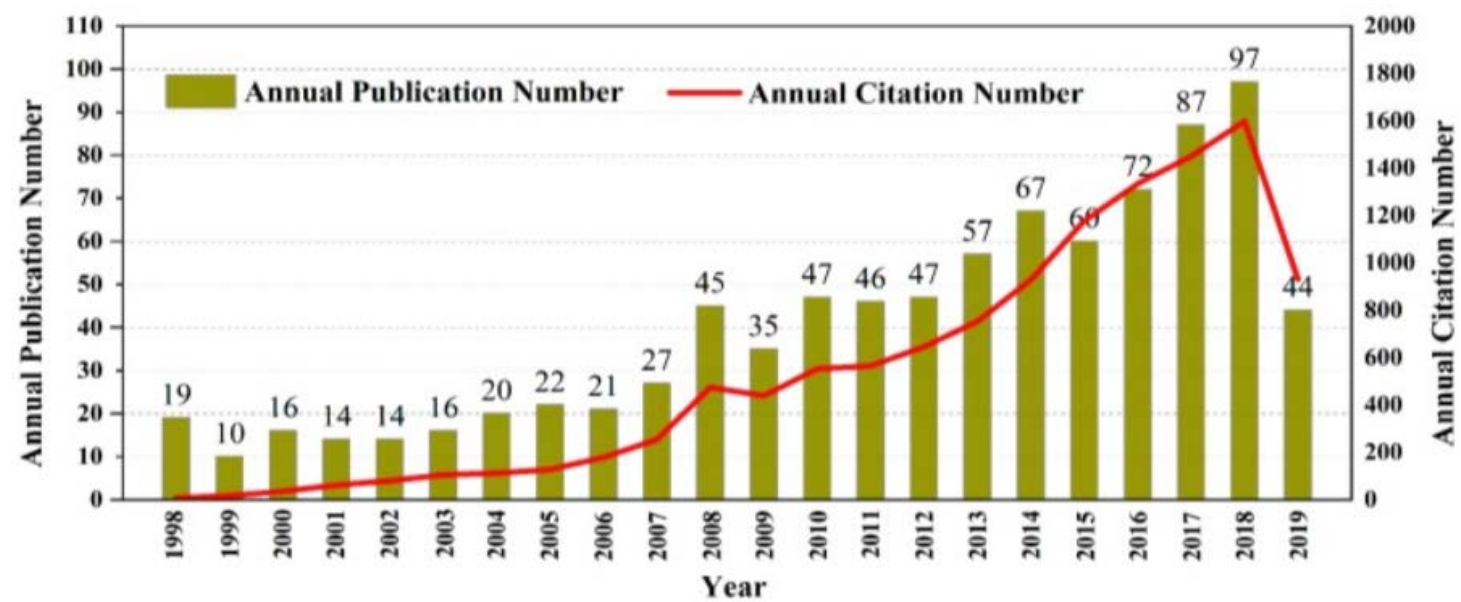

Figure 3. Annual publication and citation number from 1998 to 2019 at Web of Science [14]

As shown in Figure 7, a logic model illustrates the relationship among the research, divided into six main topics: substances, health functions, production technologies, adjuvant medicines, vinegar residues, the currently studied in the vinegar research area.

At present, most of the research relating to substance analysis in vinegar can be categorized into two classes: flavor and functional substances. The detection and isolation of substances in vinegar is predominantly performed by chromatography, while data matrix processing is done using chemometrics. Antioxidant activity represents the main research focus in relation to the health benefits of vinegar. This is probably because of the large number of studies on polyphenols, which are well-recognized antioxidants [14]. 


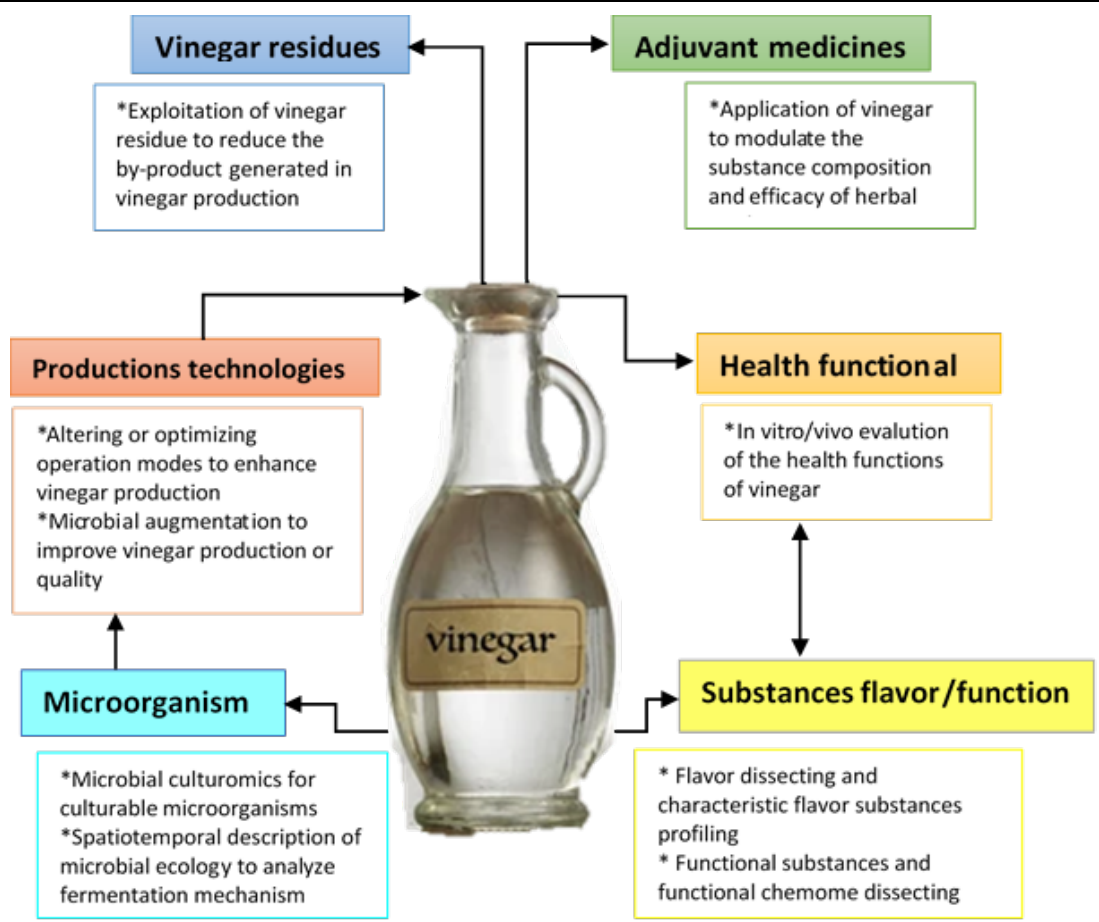

Figure 4. A logic model of related themes in current vinegar research areas [made based on the source14].

Other health functions including antiglycemic, hypolipidemic, antihypertensive, antiobesity, antidiabetic, and immunoenhancement effects associated with vinegar were also extensively reported following both in vitro or/and in vivo evaluations. Owing to the low commercial value of most vinegars, technological innovation was often considered unprofitable [15]. However, with the development of a deeper understanding of microbial ecophysiology and fermentation mechanisms, technological innovations are constantly emerging. In addition to equipment upgrading, nowadays, technological innovations in vinegar production mainly focus on the enhancement of industrial vinegar production by altering or optimizing operation modes and microbial augmentation to improve vinegar production or quality $[16,17,18]$. Adjuvant medicines is a relatively insular research area compared with the major research areas in the knowledge domain. This topic involves the study of changes to substances and the efficacy of herbal medicines such as Euphorbia kansui $[19,20,21]$ and Radix bupleuri $[22,23]$ following fry-baking with vinegar.

Last area of research concentrates on the extraction of vinegar residue. Representative articles from this domain include Ran et al.'s article [24] on the separation of acetate from fresh vinegar residue and the application of hydrothermal treatment on washed vinegar residue to enhance methane production, Song et al.'s article [25] on the evaluation of nitrogen excretion in laying hens following feeding with waste vinegar residue, and Du et al.'s article [26] on the application of vinegar residue for the control of Fusarium wilt in cucumbers.

\section{Applicable standards and legislation for vinegar in the world and in the Republic of Moldova}

Production vinegar is regulated by an extensive set of statutes, and the definition of word" vinegar" differs from country to country. FAO / WHO defines vinegar as any liquid intended for human consumption, produced exclusively from suitable products containing starch and / or sugars by the process of double fermentation, first alcoholic and then acetic. 
The residual ethanol content must be less than $0,5 \%$ in wine vinegar and less than $1 \%$ in other vinegars [8].

European countries have regional standards for vinegar produced or sold in the area. The EU has set thresholds for acidity and ethanol content. "X-vinegar" is a general definition used for products with a minimum of $5 \%(\mathrm{w} / \mathrm{v})$ acidity and a maximum of $0.5 \%$ $(\mathrm{v} / \mathrm{v})$ ethanol. Wine vinegar is obtained exclusively by acetic fermentation of wine and must have a minimum of $6 \%$ acidity $(\mathrm{W} / \mathrm{v})$ and a maximum of $1.5 \%(\mathrm{v} / \mathrm{v})$ ethanol [9].

In the USA, the FDA (Food and Drug Administration) requires that vinegar products must contain at least $4 \%$ acids. There are no FDA standards of identity for vinegar, however the "Compliance Policy Guides" establishes the labelling requirements for cider, wine, malt, sugar, sugar and vinegar blends [27].

In China, the term «vinegar» is used to indicate both fermented and artificial vinegar, according to the Chinese National Standard (CNS) definitions [28]. More recently, a new national standard code for Spices has been issued by the China State Administration Bureau for Quality and Technology, which introduces the definition of vinegar and the classification of vinegars as either fermentation or artificial products (acetic acid mixed with other ingredients, such as would be flavors).

In the Republic of Moldova exist two important arrangement documents which regulate the quality of vinegar, this is the state standard - SM SR EN 13188:2012 and government decision - HG nr.1403/2008. The decision of the Government of the Republic of Moldova HG defines vinegar as the liquid product intended for human consumption, obtained exclusively from raw materials containing starch and / or sugars by a double fermentation process, of which the first fermentation - alcoholic and the second fermentation - acetic [29]. And the state standard SM «Vinegar - product made from materials of agricultural origin» defines vinegar as a product obtained exclusively by the biological process of double fermentation, alcoholic and acetic, of liquids or other substances of agricultural origin [30].

And also, definitions of 13 types of vinegars are given, such as: wine vinegar, fruit and berry vinegar, fruit (wine) vinegar, berry vinegar, cider vinegar, spirit vinegar, grain vinegar, malt vinegar, whey vinegar, honey vinegar, spicy vinegar and aromatic vinegar, balsamic vinegar, food grade acetic acid [29].

Ethanol and acetic acid values are frequently monitored during the overall acetic fermentation process and are parameters that are governed by local legislation. Traditional methods for analyzing these parameters consist of, for ethanol, distillation of ethanol, addition of a given volume of a standard solution of potassium di-chromate and back titration of the excess of this reagent, and for acetic acid, direct titration with sodium hydroxide in the presence of phenolphthalein [31]. Given the different laws on vinegar, it is clear that acidity and residual ethanol are the two main parameters used to establish an allencompassing vinegar classification.

From the above data, it can be concluded that regulation of only 2 parameters does not protect consumers from falsification of vinegar products.

Therefore, a more precise distinction is required between genuine and wholly or partially synthetic "vinegar". Regulatory documents must include data with physical and chemical indicators (dry matter, ash, fixed acidity content, volatile acid content, etc.) for those types of vinegar that are produced and sold on the territory of the country. 


\section{Vinegar assortments on the Moldovan market}

For market research have been chosen the largest supermarket chain with the largest assortment of vinegar products, such as: Metro Cash\&Carry, Linella, Kaufland, №1, Fidesco, Green Hills, Fourchete, Velmart, Family Market. All investigated products were sorted by types and manufacturers, the results of which are presented in the figures 5 and 6.
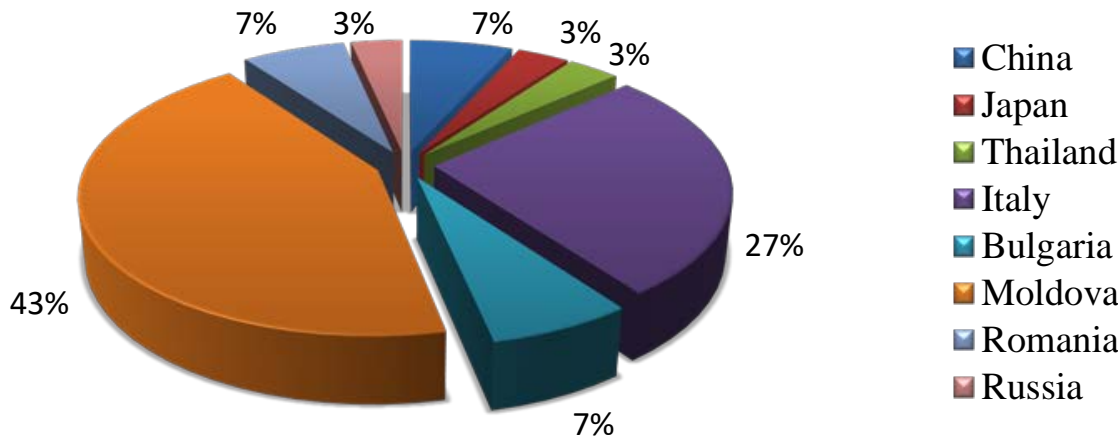

Figure 5. Countries of origin of vinegars present in the commercial networks of the Republic of Moldova.

Following the analysis of the vinegar assortment we identified that $58 \%$ are imported, most of them are balsamic vinegars imported from Italy - $23 \%$. And unsurprisingly, balsamic vinegar is considered the most common and consumed product. Italy is followed by vinegars from Romania, Bulgaria and China each being present in a proportion of $7 \%$. Other vinegars are produced in Japan, Russia, Thailand are found in insignificant quantities. The large presence of Asian producers speaks of the expansion and introduction of Asian cuisine by Moldovan HoReCa.

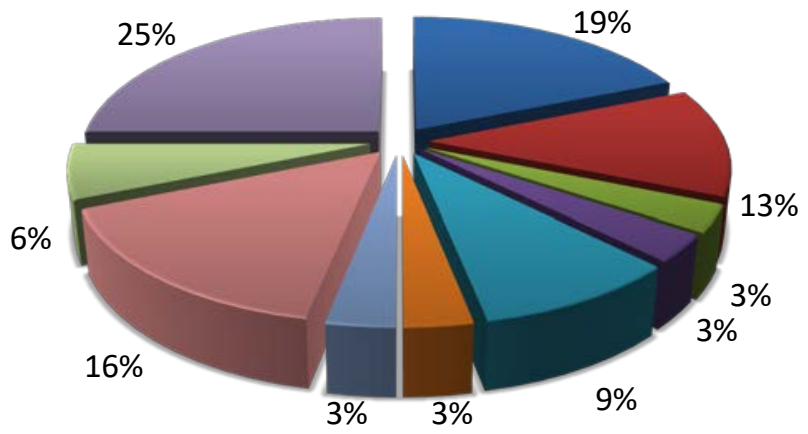

$\square$ White Table Vinegar
$\square$ Rice Vinegar
$\square$ Lemon-apple Vinegar
$\square$ Rose Vinegar
$\square$ Red wine vinegar
$\square$ White wine vinegar
$\square$ Cherry vinegar
$\square$ Apple vinegar
$\square$ Apple vinegar with honey
$\square$ Balsamic vinegar

Figure 6. The types of vinegar on the market of Moldova.

The assortment of vinegar products is presented in the figure 6 , the diagram shows that two types of vinegars: balsamic and white table vinegar, are found in large quantities and assortment on the Moldovan market. It was noticed that white table vinegar is presented with 6 and 9\% acetic acid content and is produced in particular only by local producers. They are followed by apple cider - 16\%, rice vinegar - $13 \%$ and red wine vinegar $-9 \%$. As it was noted that the amount of rice vinegar dominates over wine vinegars, this can only indicate that the Moldovan cuisine uses less vinegar than the Asian cuisine.

To find out how wide the range of vinegar products is in the Republic of Moldova, it was compared with the assortment at the international level from the book "Vinegars of the World". 
Comparative analysis of the assortment of vinegar in Moldova and globally [35]

\begin{tabular}{|c|c|c|}
\hline Categories & $\begin{array}{c}\text { Overview of vinegars around } \\
\text { the world }\end{array}$ & $\begin{array}{l}\text { Overview of vinegars in } \\
\text { Republic of Moldova }\end{array}$ \\
\hline \multirow[t]{11}{*}{ Vegetable*, cereals } & Rice vinegar & Rice vinegar \\
\hline & Bamboo vinegar & - \\
\hline & Malt vinegar & - \\
\hline & Palm (toddy) vinegar & - \\
\hline & Beer vinegar & - \\
\hline & Black vinegar & - \\
\hline & Kombucha vinegar & - \\
\hline & Onion vinegar & - \\
\hline & Tomato vinegar & - \\
\hline & Cane vinegar & - \\
\hline & - & Table vinegar \\
\hline \multirow[t]{17}{*}{ Fruit, berries } & Apple cider vinegar & Apple cider vinegar \\
\hline & Raisin (grape) vinegar & - \\
\hline & Wine vinegar & Wine vinegar \\
\hline & Sherry (jerez) vinegar & - \\
\hline & Balsamic vinegar & Balsamic vinegar \\
\hline & Coconut water vinegar & - \\
\hline & Date vinegar & - \\
\hline & Mango vinegar & - \\
\hline & Jujube vinegar & - \\
\hline & Raspberry vinegar & - \\
\hline & Blackcurrant vinegar & - \\
\hline & Blackberry vinegar & - \\
\hline & Mulberry vinegar & - \\
\hline & Plum vinegar (Ume-su) & - \\
\hline & Cranberry vinegar & - \\
\hline & Persimmon vinegar & - \\
\hline & - & Cherry vinegar \\
\hline \multirow[t]{2}{*}{ Animal } & Whey vinegar & - \\
\hline & Honey vinegar & - \\
\hline
\end{tabular}

*-Vegetable is not a botanical term and is used to refer to an edible plant part; some botanical fruits, such as tomatoes, are also generally considered to be vegetables

From the data presented in the table 1 it can be noted that out of 28 types of vinegar presented in the book "Vinegars of the World" only 6 types are found on the Moldovan market [35]. Analyzing by category and type of raw materials used for fermentation, it can be noted that out of 10 vinegars from vegetables and grains, only imported rice vinegar is present in Moldova. Although an agrarian country like Moldova is capable of producing such types as onion vinegar, tomato vinegar and possibly even malt vinegar.

There are only 4 types of fruit and berry vinegars on the Moldovan market: apple cider vinegar, white and red wine vinegar, balsamic vinegar, cherry vinegar. Rose vinegar is not 
taken into account because it is flavored vinegar, which can be based on almost any kind of vinegar. For the development of the economy in the field of vinegar production, it is possible to propose to use local fruits and berries, which the country has in full and these types of vinegars are absent on store shelves, such as: from plums, from raspberries, from black currants, from blackberries and mulberries. According to the National Food Safety Agency (ANSA), in 2019, more than 7 thousand apiaries were officially registered in Moldova [36], which confirms the possible production of honey vinegar. In figure 7 , were analyzed the local producers and the range of vinegars which they produce.
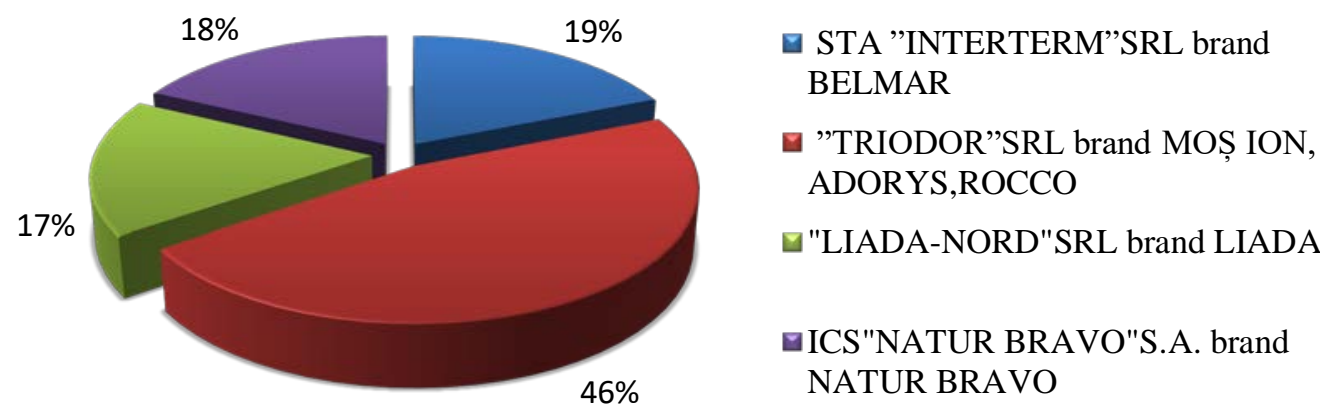

Figure 7. Structure of the vinegar market by producers in the Republic of Moldova.

Examining the assortment of vinegar products, it was revealed that only 4 manufacturers represent local products. After analyzing the products they offer, we can say that all four manufacturers have in their assortment white table vinegar $6 \%$ and $9 \%$, apple cider vinegar, as well as wine vinegar, but it should be noted that red wine vinegar dominates in terms of quantity. Only one manufacturer -" Triodor" S.R.L. producing under four brands MOȘ ION, NORA, ADORYS, ROCCO, in the assortment counted 7 types of vinegars, of which balsamic vinegar and apple cider vinegar with honey, which were not available from other manufacturers.



$\square$ White Table Vinegar

apple vinegar

$\square$ Wine vinegar

— Lemon-apple Vinegar

$\square$ Balsamic vinegar

Figure 8. Assortment of vinegars from local producers in the Republic of Moldova.

The data of figure 8 show that of the entire range of local production, almost $40 \%$ is table vinegar, with an acetic acid content of $6 \%$ and $9 \%$.

This is followed by apple cider vinegar in a volume of $26 \%$, but wine vinegar is inferior to apple cider vinegar by $5 \%$. After analyzing the data, we can say that local agricultural products are little used in the production of vinegar, which is unacceptable for an agricultural country.

And it is necessary to develop projects for the development of vinegar production based on the use of local resources, not only for economic purposes, but also to increase the range and quality of vinegar products in the Republic of Moldova. 


\section{Conclusions}

Production of vinegar is taken over global level having differential raw material, bacterial species as well as production mechanization. Following market research in Moldova was identified vinegars assortment on the shelf's distribution network. After analyzing assortment of vinegars, we identified that $57 \%$ is imported, most of them are balsamic vinegars from Italy with $23 \%$ of the total and only $43 \%$ are indigenous. Thus, it was identified which are the largest producers on the Moldovan market, these being: brand BELMAR - STA" Interterm" S.R.L., brands MOȘ ION, NORA, ADORYS, ROCCO -" Triodor" S.R.L., brand NATUR BRAVO - ICS" Natur Bravo" S.A., brand LIADA -" Liada-Nord" S.R.L. which produce the same range of vinegars. This analytical work presents the current state of affairs in the vinegar industry in Moldova. The data shows that the market is still not filled with quality local vinegar. The rapid development of the wine industry in recent years indicates the availability of a raw material base for the production of wine vinegar [37]. In cases of force majeure circumstances or poor-quality raw materials not suitable for wine, vinegar production can be an alternative for using fully agricultural products.

Acknowledgments. The research was funded by State Project 20.80009.5107.09 "Improving of food quality and safety through biotechnology and food engineering", running at Technical University of Moldova.

\section{References}

1. Barja F., Mesa M., Macías M., Bermudez I., Cantero D., Lopez J. (2003). Aspectos bioquímicos, moleculares y morfológicos de las bacterias acéticas. In: Mas, A. (Ed.). Primeras Jornadas de $I+d+i$ en la Elaboración de Vinagres de Vino. España, Pp 17-20.

2. Carbó R., De Castro J., Pujola M. (2003). Estudio de la calidad de los vinagres vínicos comerciales. Primeras Jornadas de I $+d+i$ en la Elaboración de Vinagres de Vino. España, pp 45-52

3. Muscatine D. (2003). The Vinegar of Spilamberto. Gastronomica 3(3):14-19. Disponibil: https://doi.org/10.1525/gfc.2003.3.3.14 [accesat 10.03.2021].

4. Boistean A.V., Chirsanova A.I., Rubtov S.L., Chiselita N. (2020), Identification of the optimal source for isolation of acetic bacteria, Vsyo o Myase, ISSN: 2071-2499, DOI: https://doi.org/10.21323/2071-24992020-5S-59-62

5. Bamforth W.C. (2005) Vinegar In:Food,fermentation and micro-organisms.Blachwell Science. Kundli pp.154-159.

6. Chang R.C., Lee H.C., Ou A.S.M. (2005). Investigation of the Physicochemical Properties of Concentrated Fruit Vinegar. Journal of Food and Drug Analysis, 13: 348-356.

7. Boistean A., Chirsanova A., Ciumac J., Gaina B. (2020),The particularities of the clarification process with bentonite of white wine vinegar.Food Systems.; 3(1), pp. 25-32. https://doi.org/10.21323/2618-9771-20203-1-25-32

8. FAO/WHO Food Standards Programme (1998) Conversion of European Regional Standard for Vinegar into World-wide Standard. Report No: FAO-ESN-CX/PFV-98/8. Codex Committee on Processed Fruits and Vegetables. Sess 19. Washington, DC, 16-18 March 1998. FAO, Rome.

9. Council Regulation (EC) No 1493/1999 of 17 May 1999 on the common organization of the market in wine. https://eur-lex.europa.eu/legal-content/EN/TXT/?uri=CELEX\%3A31999R1493 [accesat 10.03.2021].

10. Mintel Custom Solutions Data Presented at $2006 \mathrm{VI}$ Annual Meeting, Disponibil: https://versatilevinegar.org/market-trends/ [accesat 10.03.2021].

11. https://www.globaltrademag.com/vinegar-market-in-the-eu-increases-for-the-third-consecutive-yearreaching-871m/ [accesat 10.03 .2021 ].

12. https://www.statista.com/statistics/484745/vinegar-volume-sales-in-the-united-kingdom-uk/

13. https://www.globenewswire.com/news-release/2020/02/13/1984831/0/en/Global-Wood-Vinegar-Marketis-Expected-to-Reach-USD-2-09-Billion-by-2025-Fior-Markets.html [accesat 10.03.2021].

14.Zhang, X.L., Zheng,Y., at all.(2020)Knowledge Domain and Emerging Trends in Vinegar Research: A Bibliometric Review of the Literature from WoSCC. Foods (Basel, Switzerland), 9(2), 166. Disponibil: https://doi.org/10.3390/foods9020166 [accesat 10.03.2021]. 
15. Gullo M., De Vero L., Giudici P. (2009), Succession of selected strains of Acetobacter pasteurianus and other acetic acid bacteria in traditional balsamic vinegar. Appl. Environ. Microbiol., 75, 2585-2589.

16. Schlepütz T., Büchs J. (2013) Investigation of vinegar production using a novel shaken repeated batch culture system. Biotechnol. Prog. 29, 1158-1168.

17. Xia X., Zhu X., Yang H., Xin Y., Wang W. (2015) Enhancement of rice vinegar production by modified semi-continuous culture based on analysis of enzymatic kinetic. Eur. Food Res. Technol. 241, 479-485.

18. Qi Z., Dong D., Yang H., Xia X. (2017) Improving fermented quality of cider vinegar via rational nutrient feeding strategy. Food Chem. 224, 312-319.

19.Zhang Q., Zhang K.C., at all. (2018) Simultaneous quantification of twelve compounds in ethyl acetate extracts of Euphorbia kansui before and after fry-baked with vinegar by UPLC-MS/MS and its toxic effect on zebrafish. J. Pharm. Biomed. Anal. 155, 169-176.

20. Lou J.W., Cao L.L. et al. (2018) The toxicity and efficacy evaluation of different fractions of Kansui fry-baked with vinegar on Walker-256 tumor-bearing malignant ascites effusion rats and normal rats. J. Ethnopharmacol., 219, 257-268.

21.Jiang D., Kang A. et al. (2018) Euphorbia kansui fry-baked with vinegar modulates gut microbiota and reduces intestinal toxicity in rats. J. Ethnopharmacol. 226, 26-35.

22.Xing J., Sun H.M., Li Z.Y., Qin X.M. (2015) Comparison of volatile components between raw and vinegar baked Radix bupleuri by GC-MS based metabolic fingerprinting approach. Evid. Based Complement. Altern. Med. 653791.

23.Li Z.Y., Sun H.M., Xing J., Qin X.M., Du G.H. (2015) Chemical and biological comparison of raw and vinegarbaked Radix bupleuri. J. Ethnopharmacol. 165, 20-28.

24. Ran G., Li D., Zheng T., Liu X., Chen L., Cao Q., Yan Z. (2018) Hydrothermal pretreatment on the anaerobic digestion of washed vinegar residue. Bioresour. Technol. 248, 265-271.

25. Song Z.T., Dong X.F., Tong J.M., Wang Z.H. (2012) Effects of waste vinegar residue on nutrient digestibility and nitrogen balance in laying hens. Livest. Sci. 150, 67-73.

26. Du N., Shi L., Du L., Yuan Y., Li B., Sang T., Sun J., Shu S., Guo S. (2015) Effect of vinegar residue compost amendments on cucumber growth and Fusarium wilt. Environ. Sci. Pollut. Res. 22, 19133-19141.

27.CPG Sec 525.825 Vinegar, Definitions - Adulteration with Vinegar Eels, 1995, Disponibil: https://www.fda.gov/regulatory-information/search-fda-guidance-documents/cpg-sec-525825-vinegardefinitions-adulteration-vinegar-eels [accesat 10.03.2021].

28. Chinese National Standard, CNS 14834:2014 Edible vinegar, N5239 - Agriculture, Food, Disponibil: http://cns-standards.org/CNS_standard.asp?CODE=CNS\%2014834 [accesat 10.03.2021].

29. Hotărârea Guvernului cu privire la aprobarea Reglamentării tehnice" Oțeturi și acid acetic de uz alimentar": nr. 1403 din 09,12,2008. Disponibil: https://www.legis.md/cautare/getResults?doc_id=111718\&lang=ro

30.SM SR EN 13188:2012 «Vinegar - product made from materials of agricultural origin», Disponibil: https://shop.standard.md/public/client/\#client-standard-surface [accesat 10.03.2021].

31. Compendium of methods of analysis of wine vinegars, Office International O.I.V., Paris, France, Occurrence 2018. Disponibil: https://www.oiv.int/en/normes-et-documents-techniques/methodes-danalyse/recueildes-methodes-danalyse-des-vinaigres-de-vin [accesat 10.03.2021].

32. Galletto L., Rossetto L. (2015) A hedonic analysis of retail Italian vinegars, Wine Economics and Policy, Volume 4, Issue 1, Pages 60-68, ISSN 2212-9774.

33. Spectral Database for Organic Compounds, SDBS. [online]. [accesat 10.03.2021]. Disponibil: http://sdbs.db.aist.go.jp/sdbs/cgi-bin/cre_index.cgi.

34. Directive 2000/76/EC of the European Parliament and of the Council of 4 December 2000 on the incineration of waste, In: Official Journal of the European Communities [online]. 28.12.2000, L 332/109L332/111.

Disponibil:http://www.central2013.eu/fileadmin/user_upload/Downloads/Document_Centre/OP_Resources/ Incineration_Directive_2000_76.pdf [accesat 10.03.2021].

35. Solieri L., \& Giudici P. (2009). Vinegars of the World. Milano: Springer Milan, p.3-4, ISBN: 978-88-4700865-6

36. http://www.ansa.gov.md/uploads/files/Transparenta/Raport\%20planul\%20multianual\%20de\%20control\%2 02018\%20(3)\%20modificat.pdf [accesat 10.03.2021].

37.https://wine-and-spirits.md/ro/anul-vitivinicol-2019/ [accesat 10.03.2021]. 